\section{Individuelle variasjoner i kromatinstruktur}

I hvilken grad variasjoner i kromatinstruktur og transkripsjonsfaktorbinding kan påvirke genekspresjon og dermed bidra til variasjoner i fenotype, er ukjent. Amerikanske og engelske forskere har nå undersøkt slike variasjoner mellom individer og forskjeller mellom homologe kromosomer innen samme individ lallelspesifikk variasjon) (Science 2010; 328: 235-9).

Studiene ble gjort i en cellelinje fra to referansefamilier fra henholdsvis Europa og Afrika. $10 \%$ av aktive kromatinseter var individspesifikke og en liknende andel allelspesifikke. Både individspesifikke og allelspesifikke seter ble vanligvis overført fra foreldre til barn. Studien viser at variasjoner i kromatinstatus og transkripsjonsfaktorbinding i stor grad er genetisk betinget og kan være underliggende årsak til fenotypiske variasjoner hos mennesket.

\section{Kirurgisk sjekkliste gir mindre komplikasjoner}

Det er påvist at WHO Surgical Safety Checklist, som består av 19 punkter, er forbundet med færre komplikasjoner og nedsatt mortalitet. Når det gjelder akutte kirurgiske inngrep, har spørsmålet om en sjekkliste virkelig vil være praktisk og gunstig vært reist.

Nå viser en ny studie at sjekklisten kan være nyttig også ved akutt kirurgi (Ann Surg 2010; 251: 976-80). Forfatterne samlet inn opplysninger om forløp og utfall hos 1750 akuttkirurgiske pasienter ved åtte sykehus. Etter innføring av sjekklisten falt komplikasjonsraten fra 18,4\% til 11,7\% og mortaliteten fra 3,7\% til 1,4\%.

\title{
Langtidsskade etter 11. september 2001
}

\section{Sju år etter angrepet var det klart} nedsatt lungefunksjon hos brannmenn og redningsarbeidere i New York.

Nær 14000 personer fra brann- og redningstjenesten i New York - 12000 brannmenn og 2000 redningsmenn - var med i opprydningsarbeidet de to første ukene etter angrepet på World Trade Center i 2001. Omtrent $92 \%$ av dem er blitt fulgt i opptil sju år (1).

Resultater fra om lag 62000 spirometriundersøkelser i årene $2000-08$ viste at brannmenn som ikke røykte fikk et signifikant større fall i lungefunksjon enn ikkerøykende redningsarbeidere det første året $\left(\mathrm{FEV}_{1}\right.$ : $439 \mathrm{ml}$ versus $\left.267 \mathrm{ml}\right)$. Andelen brannmenn med lungefunksjon under nedre referansegrense økte det første året fra 3\% til $18 \%$ og stabiliserte seg deretter på $13 \%$ for resten av perioden. For redningsarbeidere var tilsvarende fra $12 \%$ til $22 \%$ det første året, deretter $22 \%$. Forskjellene forklares med at brannmennene hadde bedre lungefunksjon i utgangspunktet.

- Artikkelen viser med tydelighet at den initiale reaksjonen som hjelpemannskapene opplevde, selv ikke etter lang tid blir normalisert, sier overlege i arbeidsmedisin Håkon Lasse Leira ved St. Olavs hospital.

- Funnene samsvarer med det man kan se hos enkeltindivider etter ulykkespreget eksponering, det såkalte Reactive Airways Dysfunction Syndrome (RADS). I artikkelen er de absolutte tallene gjengitt kun for ikke-røykere, men den samme ten- densen ses også blant røykerne, kanskje i enda større grad. Det knytter seg imidlertid en viss usikkerhet til de oppgitte spirometriverdiene, siden vi ikke vet i hvilken grad de var kvalitetssikret før 2001.

Det er kjent at massiv eksponering for støv med uspesifisert innhold, røyk, gass og damp kan gi kronisk lungeskade, men her har vi fått det demonstrert i et omfang uten sidestykke, sier Leira.

\section{Geir Jacobsen}

geir.jacobsen@yale.edu

Tidsskriftet

\section{Litteratur}

1. Aldrich TK, Gustave J, Hall CB et al. Lung function in rescue workers at the World Trade Center after 7 years. N Engl J Med 2010; 362: 1263-72. 